\title{
The Relationship between Women's Employment and Divorce: An Empirical Analysis on Turkey
}

\author{
Araştırma Makalesi /Research Article
}

\section{Osman Murat TELATAR ${ }^{1}$}

\begin{abstract}
The number of studies examining the relationship between women's employment and divorce is limited in the literature. In the majority of studies on this subject and all of the studies on Turkey, female employment variable was not analyzed in detail according to marital status. In this study, unlike other studies, it is aimed to contribute to the literature by including the variable of female employment according to marital status. For this reason, relations between both married and divorced women employees and divorce in Turkey were analyzed with cointegration tests for the period 1988-2013. According to the obtained empirical results, there is no long-run relationship from the number of married women to the number of divorces (ND). On the other hand, there is a positive relationship from the number of divorces to the number of divorced employed women.
\end{abstract}

Keywords: Woman Employment, Divorce, Cointegration Tests. JEL Codes: E 24, J12, C22

\section{Kadınların İstihdamı ve Boşanma İlişkisi: Türkiye Üzerine Ampirik Bir Analiz}

ÖZ: Literatürde kadın istihdamı ve boşanma arasındaki ilişkiyi inceleyen çalışma sayısı sinırl sayıdadır. Bu konu ile ilgili yapılan çalışmaların büyük bir çoğunluğunda, Türkiye üzerine yapılan çalışmaların ise tamamında kadın istihdamı değişkeni medeni duruma göre ayrıntılı bir şekilde analiz edilmemiştir. Bu çalışmada diğer çalışmalardan farklı olarak kadın istihdamı değişkeni medeni duruma göre analize dahil edilerek literatüre katkı yapılması amaçlanmıştır. Bu amaçla Türkiye'de hem evli hem de boşanmış kadın çalışanlar ile boşanma arasındaki ilişkiler 1988-2013 dönemi için eşbütünleşme testleri ile analiz edilmiştir. Elde edilen ampirik sonuçlara göre çalışan evli kadın sayısından boşanma sayısına doğru herhangi bir uzun dönem iliş̧isi bulunmamaktadır. Buna karşın boşanma sayısından boşanmış çalışan kadın sayısına doğru pozitif yönlü bir ilişski bulunmaktadir.

Anahtar Kelimeler: Kadın İstihdamı, Boşanma, Eşbütünleşme Testleri.

JEL Kodları: E 24, J12, C22

\footnotetext{
1 Dr., Karadeniz Technical University, Faculty of Economics and Administrative Sciences, Department of Economics, omtelatar@ktu.edu.tr, orcid.org/0000-0003-3016-0534.
} 


\section{Introduction and Theoretical Background}

One of the serious increases in the female labor force participation rate came after World War II. The significant decrease in the male labor force because of deaths and injuries in the war had created a huge gap in the labor market and this gap had been tried to be compensated by the supply of female labor. After the war, especially the efforts of Western European countries to restructure made it necessary for women to enter the labor market in these regions. On the one hand, the start of production of firms, on the other hand, the development and restructuring activities in the country caused serious increases in labor demand. This increase in demand could only be supplied with the inclusion of women in the labor market. During this period, thanks to the developments in medicine, child deaths decreased and the fertility rate of women reduced, and on the other hand, with the growth in the service sector, woman's entry into the labor market gradually increased. This significant change in the labor market has brought about the change in the traditional role of women's determined by society before too.

The position of the woman, who has gained her economic freedom, in the family, her status and role in society, has started to change significantly. This situation has allowed the status of the man, the head of the family until that day, to be discussed and the male-dominant structure in the society to be shaken.

Thus, with the economic freedom of women, the revolt against the male-dominant structure increased and the divorce events have become much more comfortable to talk than in the previous periods. All these developments in the labor market have encouraged researchers to examine the relationship between woman's employment and divorce.

According to Poortman (2005), the relationship between woman's employment and divorce has two main aspects. The first is that the rise in female employment increases the number of divorces (anticipatory behavior). The entry of women into the labor market may cause divorce to take place over working hours, income, and family discussions, etc. The second direction regarding the relationship between woman's employment and divorce is that the woman who divorced or expecting a divorce enters the labor market and starts working (reversed causation).

D'amico (1983) put forward two hypotheses about the effect of income on divorce. According to the first hypothesis called income effect, the fact that a woman receives higher salaries than her husband in a family who has a pursuit of high socioeconomic status, causes families to reach a higher level of welfare and strengthens marriage. On the other hand, according to the second hypothesis called independence effect; If the wages of women are higher than that of men, discussions based on conflict and competition for status will increase and thus the number of divorces will increase (Bremmer and Kesselring, 2004: 176). According to Sander (1985), the increase in the ability of women to earn money allows them to leave an unhappy marriage and divorce or remarry. Similarly, the 
basis of the divorce is not only that the woman gains economic freedom and can no longer tolerate her husband or go into a status quarrel with him, but the desire of a divorce can be accepted by the man who falls behind in the face of the woman's economic status.

The main purpose of the study is to reveal which of the factors mentioned above is valid in the relationship between women's employment and divorce in Turkey. In the majority of studies in the literature on this subject and all of the studies on Turkey, female employment variable was taken as total or proportion, and it was not analyzed in detail according to marital status. In this study, unlike other studies, it is aimed to contribute to the literature by including the variable of female employment according to marital status. For this reason, relations between both married and divorced women employees and divorce in Turkey were tried to be determined with cointegration tests for the period 1988-2013. In the upcoming parts of the study, respectively, literature section providing information about empirical studies examining women's employment and divorce relationship, empirical analysis section in which the relationship between women employment and divorce is analyzed with time series analysis, and conclusion section where the findings obtained are evaluated and some suggestions for future studies are presented are included.

\section{Literature Review}

A large part of the studies examining the relationship between employment and marriage in the literature consists of studies examining the effect of unemployment on divorce. However, the number of studies examining the effect of women's employment on divorce is limited. A significant part of these few studies is mostly on the USA for the period after World War II. Studies examining the effect of female employment on divorce have decreased significantly for these countries due to the decrease in marriage rates notably in the EU and the USA in recent years. However, the search for this relationship has remained popular in the countries that are developing and have relatively higher marriage rates such as Turkey.

The results of the studies on the relationship between women employment and divorce differ in terms of the country dealt with, the period studied, and the empirical method applied. However, in a significant part of the studies on the subject, it has been determined that there is a positive relationship between the increase in female employment and the number of divorces. According to South (1985), the most important reason for the rise in the number of divorces after World War II in the USA is the increase in the participation rate of women in the labor market. According to Poortman and Kalmijn (2002) and Poortman (2005), there is a positive relationship between women's working hours and the number of divorces in the Netherlands, and the risk of divorce among working women is $16 \%$ higher than those who do not working. 
Table 1: Literature Summary about the Relationship between Women's Employment and Divorce

\begin{tabular}{|c|c|c|c|c|}
\hline Authors & Period & Country & Methodology & Results \\
\hline Sander (1985) & 1970 & USA & OLS (ordinary least square) & $\begin{array}{l}\text { LFPR(woman labor force participation } \\
\text { rate) } \rightarrow \text { DR (divorce rate) }(+)\end{array}$ \\
\hline South (1985) & 1948-1979 & USA & OLS & $\mathrm{LFPR} \rightarrow \mathrm{DR}(+)$ \\
\hline $\begin{array}{l}\text { Parkman } \\
(1992)\end{array}$ & 1979 & USA & Logit model estimation & $\begin{array}{l}\text { - } \mathrm{DR} \rightarrow \text { LFPR }(+) \\
\text { - Husband earnings } \rightarrow \text { LFPR (-) }\end{array}$ \\
\hline $\begin{array}{l}\text { Montalto } \\
(1994)\end{array}$ & $1968-1983$ & USA & Probit model estimation & Divorce expectation $\rightarrow$ LFPR (+) \\
\hline $\begin{array}{l}\text { Poortman and } \\
\text { Kalmijn (2002) }\end{array}$ & 1998 & $\begin{array}{l}\text { Netherland } \\
\mathrm{s}\end{array}$ & Logistic regression analysis & WT(woman work time) $\rightarrow$ DR (+) \\
\hline $\begin{array}{l}\text { Bremmer and } \\
\text { Kesselring }(200 \\
4)\end{array}$ & 1960-2001 & USA & $\begin{array}{l}\text {-Johansen cointegration } \\
\text {-VAR (Vector } \\
\text { Autoregressive) analysis }\end{array}$ & $\begin{array}{l}\text { - cointegrated } \\
\text { - } \mathrm{LFPR} \rightarrow \mathrm{DR}(+) \\
\text { (impulse-response function) }\end{array}$ \\
\hline $\begin{array}{l}\text { Poortman } \\
(2005)\end{array}$ & 1998 & $\begin{array}{l}\text { Netherland } \\
\mathrm{s}\end{array}$ & Survey Estimation & $\mathrm{WT} \rightarrow \mathrm{DR}(+)$ \\
\hline $\begin{array}{l}\text { Kneip and } \\
\text { Bauer (2007) }\end{array}$ & $1960-2005$ & $\begin{array}{l}18 \\
\text { European } \\
\text { countries }\end{array}$ & Panel regression analysis & $\begin{array}{l}\text { - Divorce risk } \rightarrow \text { LFPR }(+) \\
\text { - Crude DR } \rightarrow \text { LFPR }(+)\end{array}$ \\
\hline $\begin{array}{l}\text { Bozkaya } \\
(2013)\end{array}$ & 1988-2012 & Turkey & VAR analysis & $\begin{array}{l}\text { - divorced woman employment } \rightarrow \text { LFPR } \\
\text { (for variance decompositions) }\end{array}$ \\
\hline $\begin{array}{l}\text { Kutlar et al. } \\
(2012)\end{array}$ & 1988-2009 & Turkey & $\begin{array}{l}\text {-Johansen-Juelius } \\
\text { cointegration test } \\
\text {-Granger causality test }\end{array}$ & $\begin{array}{l}\text { cointegrated } \\
\mathrm{LFPR} \rightarrow \mathrm{DR}(+)\end{array}$ \\
\hline $\begin{array}{l}\text { Kiliç and } \\
\text { Öztürk (2014) }\end{array}$ & $2002-2008$ & Turkey & Probit model estimation & $\begin{array}{l}\text { Household income } \rightarrow \text { LFPR (-) } \\
\text { (urban) }\end{array}$ \\
\hline $\begin{array}{l}\text { Üçler ve } \\
\text { Kızılkaya } \\
(2014)\end{array}$ & 2004-2013 & Turkey & Panel cointegration analysis & $\begin{array}{l}\text { whole country: } \\
\text { - woman employment } \rightarrow \mathrm{DR}(+) \\
\text { regional: } \\
\text { - woman employment } \rightarrow \mathrm{DR}(-) \\
\text { (for northeast and southeast Anatolian } \\
\text { regions) } \\
\text { - woman employment } \rightarrow \mathrm{DR}(-) \\
\text { (for other regions) }\end{array}$ \\
\hline $\begin{array}{l}\text { Çatalbaş } \\
(2015)\end{array}$ & $2008-2013$ & $\begin{array}{l}\text { Turkey } \\
\text { (12 sub- } \\
\text { regions) }\end{array}$ & Panel regression analysis & - $\mathrm{DR} \rightarrow \operatorname{LFPR}(+)$ \\
\hline $\begin{array}{l}\text { Cafrı and } \\
\text { Çukadar } \\
(2018) \\
\end{array}$ & 2013 & Turkey & Spatial analysis- OLS & woman employment $\rightarrow$ crude DR \\
\hline $\begin{array}{l}\text { Vignoli et al. } \\
(2018)\end{array}$ & $\begin{array}{l}\text {-2004-2005/ } \\
\text { 2008-2009 } \\
\text { (Germany, } \\
\text { Hungary) } \\
\text {-2009 (Italy) } \\
\text {-2010-2011 } \\
\text { (Poland) }\end{array}$ & $\begin{array}{l}\text { Germany, } \\
\text { Hungary, } \\
\text { Italy and } \\
\text { Poland }\end{array}$ & Survey Estimation & $\begin{array}{l}\text { - woman employment } \rightarrow \text { DR }(+) \\
\text { (Italy and Poland) } \\
\text { - anticipation behavior is valid } \\
\text { (Italy) }\end{array}$ \\
\hline Yazıc1 (2018) & $1988-2016$ & Turkey & Regression analysis & number of divorces $\rightarrow$ LFPR (+) \\
\hline Zengi (2018) & $2000-2013$ & Turkey & OLS & $\begin{array}{l}\text { Divorced woman rate } \rightarrow \text { LFPR (+) } \\
\text { (in LFPR) }\end{array}$ \\
\hline
\end{tabular}


On the other hand, also there are studies in the literature that reveal the increase in female employment as a result of the increase in the divorce risk or the number of divorces, which is called the reverse causation. Spitze and South (1985), Micheal (1985), Shapiro and Shaw (1985), and Johnson and Skinner (1986) are among the pioneering studies on this subject. According to Peters (1986), Greene and Quester (1982), Lombardo (1999), women at risk of divorce take precaution against this situation with higher labor force participation rate and more working (Bremmer and Kesselring, 2004: 176). Similarly, according to Stevenson (2008), woman's participation in the labor force increases when the risk of divorce increases in the years before the divorce.

In the literature, studies that empirically examine the relationship between women's employment and divorce are shown in the Table 1.

\section{Empirical Analysis and Results}

\subsection{Data and Methodology}

In the study, the relationships between women's employment and divorce in Turkey for the period 1988-2013 will be tested empirically by using annual data. For this purpose, the number of married employed women (MEW), the number of divorced employed women (DEW) and the number of divorces (ND) data were obtained from Turkish Statistical Institute (TUIK), and Gross domestic product per capita (GDP) data was obtained from the World Bank database (WDI). The main reason for the working period to cover 1988-2013 is that employment data began to be published since 1988 and, women's employment data were not published according to marital status after 2013. Since the relevant data is calculated only annually, the data set of the study includes the annual frequency.

The following models have been established to investigate the relationship between variables. The letter $\mathrm{L}$ in front of the variables indicates that the relevant variable is inserted into the model in logarithmic form.

$$
\begin{aligned}
& \mathrm{LND}_{\mathrm{t}}=\alpha_{0}+\alpha_{1} \mathrm{LMEW}+\alpha_{2} \mathrm{LGDPP}+\varepsilon_{\mathrm{t}} \\
& \mathrm{LDEW}_{\mathrm{t}}=\beta_{0}+\beta_{1} \mathrm{LND}+\beta_{2} \mathrm{LGDPP}+\mathrm{u}_{\mathrm{t}}
\end{aligned}
$$

\subsection{Descriptive statistics}

The descriptive statistics of the variables used in the study are presented in Table 2 which shows the means, standard deviations, and the maximum and minimum values of the series. 
Table 2: The Descriptive Statistics of Variables

\begin{tabular}{ccccc}
\hline \multirow{2}{*}{$\begin{array}{c}\text { Descriptive } \\
\text { Statistics }\end{array}$} & $\begin{array}{c}\text { ND } \\
(* 1000)\end{array}$ & $\begin{array}{c}\text { MEW } \\
(* 1000)\end{array}$ & $\begin{array}{c}\text { DEW } \\
(* 1000)\end{array}$ & $\begin{array}{c}\text { GDPP } \\
\text { (USD) }\end{array}$ \\
\hline Mean & 66503.81 & 4108.615 & 163.1538 & 6372.175 \\
Maximum & 125305 & 5573 & 436 & 8728.756 \\
Minimum & 22513 & 3284 & 63 & 4668.142 \\
Std. Dev. & 39730.88 & 529.9756 & 107.7704 & 1247.327 \\
Observations & 26 & 26 & 26 & 26 \\
\hline
\end{tabular}

As it is seen in Table 2, the mean of number of divorces is 66.5 million. While the maximum number of divorces occurred in 2013 , the number of divorces reached the minimum level in 1988. In the same period, the mean of the number of working married women and working divorced women is nearly 4.1 and 0.163 million respectively.

\subsection{Correlation Analysis}

Although the correlation analysis does not provide precise information about the short- or long-run relationship between the variables, it provides preliminary information about the extent of the relationship between the variables.

Table 3: The Results of Correlation Analysis

\begin{tabular}{|c|c|c|c|c|}
\hline Variables & LND & LMEW & LDEW & LGDPP \\
\hline LND & 1 & & & \\
\hline LMEW & $\begin{array}{l}0.378 \\
(0.056)\end{array}$ & 1 & & \\
\hline LDEW & $\begin{array}{l}0.898 \\
(0.000)\end{array}$ & $\begin{array}{l}0.604 \\
(0.001)\end{array}$ & 1 & \\
\hline LGDPP & $\begin{array}{l}0.872 \\
(0.000)\end{array}$ & $\begin{array}{l}0.437 \\
(0.025)\end{array}$ & $\begin{array}{l}0.948 \\
(0.000)\end{array}$ & 1 \\
\hline
\end{tabular}

As it is seen in Table 3, all correlation coefficients are meaningful at least at the $5 \%$ significant level. These results point out the existence of correlation relationships among the variables. While the relationship between LDEW and LGDPP is the most powerful, LND and LMEW is the weakest (correlation relationship). As a result, there is a linear relationship between the number of working women, per capita income and the number of divorces. In order to determine the direction and degree of this linear relationship between variables, it was first investigated whether the variables contain unit root. Therefore, the most commonly used Augmented Dickey Fuller (ADF) and Phillips Perron (PP) unit root tests were applied to the variables. 


\subsection{Unit Root Tests}

The variables used in the cointegration analysis in the study were first subjected to $\mathrm{ADF}$ and PP unit root tests and the results are given in Table 4.

Table 4: The Results of Unit Root Tests

\begin{tabular}{|c|c|c|c|c|}
\hline \multirow[b]{2}{*}{ Variables } & \multicolumn{2}{|c|}{ ADF } & \multicolumn{2}{|c|}{ PP } \\
\hline & $\begin{array}{c}\text { Constant and } \\
\text { Trend }\end{array}$ & Constant & $\begin{array}{c}\text { Constant and } \\
\text { Trend }\end{array}$ & Constant \\
\hline LMEW & $-1.196(0)$ & $-0.703(1)$ & -1.234 & -0.762 \\
\hline$\Delta \mathrm{LMEW}$ & $-5.209(0)^{* * *}$ & $-4.923(0)^{* * *}$ & $-5.242^{* * *}$ & $-4.923^{* * *}$ \\
\hline LDEW & $-1.417(3)$ & $2.500(3)$ & -1.665 & -1.887 \\
\hline$\Delta$ LDEW & $-5.080(2)^{* * *}$ & $-1.843(3)$ & $-24.111^{* * *}$ & $-7.181^{* * *}$ \\
\hline LND & $-2.060(0)$ & $-0.776(0)$ & -2.060 & -0.771 \\
\hline$\Delta \mathbf{L N D}$ & $-4.418(0)^{* * *}$ & $-4.552(0)^{* * *}$ & $-4.392^{* * *}$ & $-4.510^{* * *}$ \\
\hline LGDPP & $-2.788(0)$ & $-0.209(0)$ & -2.839 & -0.068 \\
\hline$\Delta$ LGDPP & $-5.544(0)^{* * *}$ & $-5.672(0)^{* * *}$ & $-5.567^{* * *}$ & $-5.695^{* * *}$ \\
\hline
\end{tabular}

Table 4, presents the results of ADF and PP unit root tests (for the variables both in levels and difference). The results indicate that all variables are non-stationary at the $1 \%$ significant level, meaning that they are integrated at order one [I(1)]. Since all the variables are first-order stationary, the long-term relationship between them was analyzed with the help of the Johansen Multivariate Cointegration Test.

\subsection{Co-integration Analysis}

\subsubsection{Johansen Procedure}

The Johansen Procedure relies on the relationship between rank of matrix and its characteristics of roots. In the Johansen Procedure, the VAR (p) model is considered first as follows (Enders, 2010; 386-391).

$$
\mathrm{X}_{\mathrm{t}}=\mathrm{A}_{1} \mathrm{X}_{\mathrm{t}-1}+\mathrm{A}_{2} \mathrm{X}_{\mathrm{t}-2}+\ldots \ldots \mathrm{A}_{\mathrm{p}} \mathrm{X}_{\mathrm{t}-\mathrm{p}}+\varepsilon_{\mathrm{t}}
$$

where: $X_{t}$ is a $(n \times 1)$ variable vector, $A_{i}$ is a $(n \times n)$ matrix of parameters.

This VAR (p) model can be expressed as the Vector Error Correction Model as follows:

$$
\Delta \mathrm{X}_{\mathrm{t}}=\Gamma_{1} \Delta \mathrm{X}_{\mathrm{t}-1}+\ldots \ldots \Gamma_{\mathrm{p}-1} \Delta \mathrm{X}_{\mathrm{t}-\mathrm{P}+1}+\Pi \mathrm{X}_{\mathrm{t}-1}+\varepsilon_{\mathrm{t}}
$$

where: $\mathrm{I}$ is an (nxn) identity matrix

$\Gamma_{1}=-\left(A_{i+1}+\ldots . .+A_{p}\right)(i=1,2 \ldots . p-1)$,

$\Pi=\left(A_{1}+A_{2}+\ldots . . A_{p}-I_{n}\right)$ 
In equation (4) $X_{t}$ is variables vector, $\Gamma$ is parameters vector, $\Pi$ an (pxp) matrix which shows the long run relationships among variables, and $\varepsilon_{\mathrm{t}}$ is error term. The rank of $\Pi$ is equal to the number of independent cointegrating vectors. If rank $(\Pi)=0, X_{t}$ transforms a first difference VAR model which means that the variables in $X_{t}$ are not cointegrated. On the other hand, if $\operatorname{rank}(\Pi)=r<p$, there are number of $\mathrm{p}$ cointegrating vectors.

The trace and maximum eigenvalue are two test statistics to find the rank of $\Pi$.

$$
\begin{array}{ll}
\lambda_{\text {trace }}=-T \sum_{i=r+1}^{p} \ln \left(1-\lambda_{i}\right) & \\
\lambda_{\text {max }}=-T \ln \left(1-\lambda_{r+1}\right) & 0 \leq \mathrm{r} \leq \mathrm{p}
\end{array}
$$

If the two test statistics are greater than the related critical table values, the null hypothesis is rejected. The results of Johansen multivariate cointegration analysis are given in Table 5.

\begin{tabular}{|c|c|c|c|c|c|c|c|}
\hline \multirow{2}{*}{ Model } & \multirow{2}{*}{$\begin{array}{c}\text { Null } \\
\text { Hypothesis }\end{array}$} & \multicolumn{2}{|c|}{ Statistics } & \multicolumn{2}{|c|}{$\begin{array}{c}\text { Critical Values } \\
(0.05)\end{array}$} & \multicolumn{2}{|c|}{ Probability } \\
\hline & & Trace & $\begin{array}{l}\text { Max- } \\
\text { Eigen }\end{array}$ & Trace & $\begin{array}{l}\text { Max- } \\
\text { Eigen }\end{array}$ & Trace & $\begin{array}{l}\text { Max- } \\
\text { Eigen }\end{array}$ \\
\hline \multirow{2}{*}{ (1) } & $\mathrm{r}=0$ & 16.430 & 12.952 & 29.797 & 21.131 & 0.681 & 0.456 \\
\hline & $\mathrm{r} \leq 1$ & 3.477 & 3.280 & 15.494 & 14.426 & 0.941 & 0.926 \\
\hline \multirow{2}{*}{ (2) } & $\mathrm{r}=0$ & 30.216 & 18.985 & 29.797 & 21.131 & 0.044 & 0.097 \\
\hline & $\mathrm{r} \leq 1$ & 11.228 & 8.725 & 15.494 & 14.426 & 0.197 & 0.309 \\
\hline
\end{tabular}

Table 5: The Results of Cointegration Analysis

As shown in Table 5, while both test-statistics do not reject the null hypothesis of no co-integration rank at the 5\% significance level for Model (1), the null hypothesis rejected at the $10 \%$ significance level for Model (2). According to the results of cointegration analysis there is only one cointegration vector for Model (2). Therefore, the results insisted that there is equilibrium long run relationships among the variables. According to the results of Johansen cointegration test, while there is no long-run relationship between the number of married employed women and the number of divorces, there is a long-run relationship between the number of divorces and the number of divorced employed women. According to the results of the normalized cointegration equation given in Table 6 , as the per capita income and number of divorces increase, the number of divorced employed women increases.

Table 6: Normalized Cointegrating Equation of Model (2)

(Dependent Variable: LDEW)

\begin{tabular}{ccc}
\hline LDEW & LND & LGDPP \\
\hline 1.0000 & -0.2048 & -0.0004 \\
& $(0.119)$ & $(6.6 \mathrm{E}-05)$ \\
\hline Note: Number in the parenthesis is the standard error of the variable. \\
\hline
\end{tabular}


After determining the co-integration between the variables for Model (2), the study covers vector error correction model (VECM). Estimated results of error correction model are shown in Table 7.

Table 7: The Results of Vector Error Correction Model (VECM) Estimation (Dependent Variable: $\triangle \mathrm{LDEW}$ )

\begin{tabular}{|c|c|c|}
\hline Variables & Coef. & t-stat. \\
\hline ECT(-1) & $-0.504^{* * *}$ & -4.398 \\
\hline$\Delta \operatorname{LDEW}(-1)$ & -0.220 & -1.509 \\
\hline$\Delta \mathrm{LND}(-1)$ & 0.062 & 0.569 \\
\hline$\Delta$ LGDPP & $0.001^{* *}$ & -2.249 \\
\hline Constant & $0.109^{* * *}$ & 3.826 \\
\hline \multicolumn{3}{|c|}{ Diagnostic Tests } \\
\hline $\mathrm{R}^{2}$ & \multicolumn{2}{|l|}{0.599} \\
\hline F-statistic & \multicolumn{2}{|l|}{$7.096^{* * *}$} \\
\hline DW & \multicolumn{2}{|l|}{1.962} \\
\hline$\chi^{2} \mathrm{LM}$ & \multicolumn{2}{|c|}{$8.663(0.468)$} \\
\hline$\chi^{2}$ WHITE & \multicolumn{2}{|c|}{$48.872(0.437)$} \\
\hline \multicolumn{3}{|c|}{$\begin{array}{l}\text { Notes: }{ }^{* * *} \text { and }{ }^{* *} \text { denote the statistical significance level at the } 1 \% \text { and } 5 \% \text {, } \\
\text { respectively. Number in the parenthesis is the p-values. ECT } T_{t-1} \text { refers the first lag } \\
\text { of error correction term. } \triangle \text { refers the first difference of the variable. }\end{array}$} \\
\hline
\end{tabular}

According to results of error correction model shown in Table 7, the lag of error correction term [ECT(-1)] is calculated negative and meaningful for statistical as expected. Thus, the findings obtained support the results of the Johansen cointegration analysis, which states that the variables are co-integrated. More clearly, the ECT value (0.504) shows that a deviation from current equilibrium with the amount of $50 \%$ has been eliminated at long-run. At the same time these findings mean that there is an adjustment mechanism from short run to long run.

\subsubsection{Fully Modified Ordinary Least Squares Approach}

Owing to the fact that the model variables are co-integrated, Fully Modified Ordinary Least Squares (FMOLS) approach can be used for estimating long-run parameters. Therefore, FMOLS procedure is being applied for Model (2). 
Table 8: The Results of Fully Modified OLS Estimation (Dependent Variable: LDEW)

\begin{tabular}{lll}
\hline Variables & Coef. & t-stat. \\
\hline LND & 0.087 & $2.477^{* *}$ \\
LGDPP & 0.452 & $2.163^{* *}$ \\
Constant & -3.735 & $-2.508^{* *}$ \\
$\mathrm{R}^{2}=0.959$ & & \\
\hline
\end{tabular}

Notes: ${ }^{* *}$ denotes the statistical significance level at the $5 \%$.

Table 8 presents the estimated results of FMOLS. According to FMOLS results, LND and LGDPP variables have positive impacts on LDEW. The results suggest that one percent increase in the LND and LGDPP increases the LDEW $0.08 \%$ and $0.4 \%$ respectively.

\section{Conclusion}

The relationship between women employment and divorce started to be discussed in industrialized western countries, especially the USA, after World War II. In the Post-war Period, both the efforts of firms to increase their production capacities and the restructuring processes of the countries caused a significant increase in labor demand. In the following period, the growth in the service sector accelerated woman's entry into the labor market. This increase in woman's labor market entry has led to changes in the role of women in the family and society, in many ways, primarily in economic, social and demographic. Thus, the relationship between women's employment and divorce has become a topic of interest for researchers.

In the literature, the relationship between women's employment and divorce may basically emerge in two ways. According to the view which is called anticipatory behavior, the increase in female employment brings with it the divorce situation. According to the so-called reversed causation, there is a direct relationship between the probability of divorce or the number of divorces and female employment. The purpose of this study is to determine whether there is any relationship between female employment and divorce in Turkey. Therefore, the relationships between the number of working women and the number of divorces in terms of their marital status (married or divorced) were investigated by the Johansen multivariate cointegration test.

The empirical results show that there is no long-run relationship from the number of married women (MEW) to the number of divorces (ND). On the other hand, there is a positive relationship from the number of divorces to the number of divorced employed women (DEW). According to the long-run coefficients, as the number of divorces increases, the number of divorced worked women increases. In addition, the coefficient of gross domestic product per capita (GDPP) which 
takes place as the instrumental variable came out positive. Accordingly, as the GDPP increases, the DEW variable increases. This long-run relationship between variables was also investigated using the FMOLS approach. The findings are consistent with the Johansen cointegration test results.

The results of both cointegration tests applied in the empirical part of the study have revealed that anticipatory behavior that's not available, but the view of reversed causation is valid in Turkey for the 1988-2013 periods. Accordingly, the rise in the number of divorces increases woman's entry into the labor market and woman's employment. On the other hand, why the view of anticipatory behavior is invalid may be resulted from the relevant effect having no appear in Turkey. Women who gain economic freedom by entering the labor market may tend to continue their marriage for the sake of on the one hand, intense family and community pressure, on the other hand, not to be branded as the divorced woman or not to be exposed to violence by the spouse. Undoubtedly, the validity of this situation can only be revealed in the result of a more comprehensive interdisciplinary study in which the psychological, sociological and economic aspects of the subject will be handled together.

\section{References}

Bremmer, D. and Kesselring, R. (2014). Divorce and Female Labor Force Participation: Evidence from Times-Series Data and Cointegration. Atlantic Economical Journal, 32(3), 157-190.

Bozkaya, G. (2013). Kadınların İşgücüne Katılımını Belirleyen Faktörler: Türkiye Üzerine Bir Analiz. Sosyal Bilimler Dergisi, 3(5), 69-89.

Cafrı, R. and Çukadar, Ö. P. (2018). Boşanmanın Sosyo-Ekonomik Nedenleri Üzerine Mekânsal Ekonometrik Bir İnceleme. International Journal of Economic and Administrative Studies, Prof. Dr. Harun Terzi Özel Sayıs1, 407424.

Çatalbaş, K. G. (2015). Kadınların İşgücüne Katılımını Belirleyen Faktörlerin Belirlenmesi: Panel Veri Yaklaşımı. Kafkas Üniversitesi İktisadi ve İdari Bilimler Fakültesi Dergisi, 6(10), 249-280.

D'amico, R. (1983). Status Maintenance or Status Competition? Wife's Relative Wages as a Determinant of Labor Supply and Martial Instability. Social Forces, 61(4), 1186-1205.

Dickey, D. A. and Fuller, W. A. (1979). Distribution of the Estimators for Autoregressive Time-Series with a Unit Root. Journal of the American Statistical Association, 74(366), 427-431.

Enders, W. (2010). Applied Econometrics Time Series, 3th. Ed., John Wiley \& Sons, Inc. 
Greene, W. H. and Quester, A. Q. (1982). Divorce Risk and Wives' Labor Supply Behavior. Social Science Quarterly, 63(1), 16-27.

Johansen, S. and Juselius, K. (1990). Maximum Likelihood Estimation and Inferences on Cointegration with Applications to the Demand for Money. Oxford Bulletin of Economics and Statistics, 52(2), 169-210.

Johansen, S. (1991). Estimation and Hypothesis Testing of Cointegrated Vectors in Gaussian Vector Autoregressive Models. Econometrica, 59(6), 1551-1580.

Johnson, W. and Skinner, J. (1986). Labor Supply and Marital Separation. The American Economic Review, 76(3), 455-469.

Kılıç, D. and Öztürk, S. (2014). Türkiye'de Kadınların İşgücüne Katılımı Önündeki Engeller ve Çözüm Yolları: Bir Ampirik Uygulama. Amme İdaresi Dergisi, 47(1), 107-130.

Kneip, T. and Bauer, G. (2007). Effects of Different Divorce Probabilities on Female Labor Force Participation and Fertility. http://www.mzes.unimannheim.de/publications/wp/wp-102.pdf?gathStatIcon=true (Erişim: 16.03.2018).

Kutlar, A., Erdem, E. and Aydın, F. F. (2012). Kadınların İşgücüne Katılması İle Doğurganlık, Boşanma ve Ücret Haddi Arasındaki İlişki: Türkiye Üzerine Bir Araştırma. Bilgi Ekonomisi ve Yönetimi Dergisi, 7(1), 149-168.

Lombardo, K. V. (1999). Women's Rising Market Opportunities and Increased Labor Force Participation. Economic Inquiry, 37(2), 195-212.

Micheal, R. T. (1985). Consequences of the Rise in Female Labor Force Participation Rates: Questions and Probes. Journal of Labor Economics, 3(1), 117-146.

Montalto, P. C. (1994). Married Women's Labor Force Participation as Divorce Insurance. Financial Counseling and Planning, 5, 191-206.

Parkman, M. A. (1992). Unilateral Divorce and the Labor-Force Participation Rate of Married Women, Revisited. The American Economic Review, 82(3), 671-678.

Peters, E. H. (1986). Marriage and Divorce: Informational Constraints and Private Contracting. The American Economic Review, 76(3), 437-454.

Phillips, P. C. B. and Perron, P. (1988). Testing for a Unit Root in Time-Series Regression. Biometrika, 75(2), 334-346.

Poortman, A. and Kalmijn, M. (2002). Women's Labour Market Position and Divorce in the Netherlands: Evaluating Economic Interpretations of the Work Effect. European Journal of Population, 18, 175-202. 
Poortman, A. (2005). Women's Work and Divorce: A Matter of Anticipation? A Research Note. European Sociological Review, 21(3), 301-309.

Sander, W. (1985). Women, Work, and Divorce. The American Economic Review, 75(3), 519-523.

Shapiro, D. and Shaw, L. (1985). Growth in Supply Force Attachment of Married Women: Accounting for Changes in the 1970s. Southern Economic Journal, 6(3), 307-29.

South, J. S. (1985). Economic Conditions and the Divorce Rate: A Time-Series Analysis of the Postwar United States. Journal of Marriage and Family, 47(1), 31-41.

Spitze, G. and South, S. (1985). Women's Employment, Time Expenditure, and Divorce. Journal of Family Issues, 6(3), 307-29.

Stevenson, B. (2008). Divorce Law and Women's Labor Supply. Journal of Empirical Legal Studies, 5(4), 853-873.

Üçler, G. and Kızılkaya O. (2014). Kadın İstihdamının Boşanma ve Doğurganlık Üzerine Etkileri: Türkiye Üzerine Bölgesel Panel Veri Analizi. Akademik, Sosyal Araştırmalar Dergisi, 2(2), 28-43.

Vignoli, D., Styrc, M., Matysiak, A. and Tocchioni, V. (2018). The positive impact of women's employment on divorce: Context, selection, or anticipation?. Demographic Research, 38, 1057-1110.

Yazıcı, M. A. (2018). Medeni Durumun ve Eğitimin Kadınların İşgücüne Katılımına Etkisi: TÜİK Verileri Üzerine Ampirik Bir Çalışma. Iktisat Politikası Araştırmaları Dergisi, 5(2), 101-116.

Zengi, C. A. (2018). Türkiye'de Medeni Durumun Kadın İstihdamına Etkisi. Social Sciences Studies Journal, 4(18), 1659-1670. 